\title{
Editorial
}

Journal of Innate

Immunity
J Innate Immun 2018;10:1-2

DOI: $10.1159 / 000485754$

Published online: January 11, 2018

\section{Going Fishing}

With the discovery of neutrophil extracellular traps (NETs) by Volker Brinkmann and his colleagues in 2004 [1], a new chapter in the book of innate immunity was opened. It is more than obvious that this chapter has not yet been closed since many researchers are still contributing to it. It was first believed that NETs play an important role in immobilizing bacterial pathogens, but evidence is now accumulating that they are also involved in many other processes, such as the induction of inflammatory reactions [2,3]. Moreover, NETs can promote immunothrombotic processes since they activate the coagulation system [4]. This said, there is also a growing number of publications reporting that overwhelming NET formation can contribute to a plethora of pathological processes $[5,6]$. A discussion has therefore arisen as to whether NETs can act as a double-edged sword. This is exemplified by a number of articles with titles such as "Neutrophil Extracellular Traps as a New Paradigm in Innate Immunity: Friend or Foe?" [7] or "Neutrophil Extracellular Traps - The Dark Side of Neutrophils" [8].

As is the case for many other inflammatory host responses, the amplitude of NET induction will determine whether their formation is part of an adequate immune reaction or a pathophysiological mechanism used by invading bacteria to cause systemic complications. In patients with severe infectious diseases, systemic inflammatory responses, such as a cytokine storm, are part of the clinical picture $[9,10]$. These life-threatening conditions are often a consequence of a pathological activation of pattern recognition receptors (PRRs) by microbial pathogens [11]. However, the question remains of how the host can distinguish between commensal and pathogenic bacteria, since both utilize similar ligands for the activation of PRRs. One concept addressing this question was published in 2002 by Polly Matzinger [12] who postulated that a danger signal is needed to discriminate between self and non-self. Though her model concerns the adaptive immune system and the prevention of autoimmune reactions, the danger model can also be applied to innate immune mechanisms, as described by Philippe Sansonetti [13] in 2016.

Today, we know that during infection the host can mobilize so-called damage-associated pattern molecules (DAMPs), also known as alarmins, triggering innate immune responses [14]. One of the best-characterized proteins within this family of inflammatory mediators is high mobility group box-1 (HMGB1) [15], but also extracellular histones and antimicrobial peptides (AMPs) have lately attracted significant attention [16]. Thus, it seems plausible that DAMPs provide the danger signals that the innate immune system needs to distinguish whether a PRR is activated by a commensal or pathogenic microorganism. Also, here it seems that an overwhelming release of DAMPs cause more harm than benefit, since the inflammatory DAMP response can reach pathological levels under certain conditions. For instance, extracellular histones, when released at a high concentration, can cause death within minutes, as shown in a murine sepsis model by $\mathrm{Xu}$ et al. [17]. The host should therefore have developed counter mechanisms that help to decrease DAMP signaling processes and prevent the induction of pathological inflammatory reactions. So far, the regulation of 
DAMPs has not been intensively studied. However, there have been some interesting hints reported in the literature. Many DAMPs, including HMGB1 and extracellular histones as well as AMPs, have an overall positive net charge. Cells like endothelial and epithelial cells express proteins such as $\mathrm{p} 33$ and osteopontin, respectively, which are highly negatively charged $[18,19]$. Both proteins have in common that their binding to DAMPs, including extracellular histones and AMPs, abolish their inflammatory activities [20,21]. Thus, it is tempting to speculate that proteins like p33 and osteopontin are endogenous regulators of DAMP signaling. However, more work is needed to support this hypothesis.

In this issue of Journal of Innate Immunity, Ariane Neumann and her coworkers [22] show that, in addition to downregulating inflammatory host reactions, p33 is also able to annul histone- and LL-37-induced NET formation. To this end, neutrophils take up extracellular p33, which can be released for instance from necrotic endothelial cells. Once internalized, p33 blocks the activity of myeloperoxidase, which is otherwise required for the release of the nucleic material. These findings are in line with the concept that the host can produce its own regulators that dampen an otherwise overwhelming and deleterious immune response. This is a very interesting and still unexplored area of research. We therefore believe that future work will show whether regulation of DAMP signaling can be used as a treatment to prevent the induction of overwhelming and uncontrolled host responses to severe and life-threatening infections.

\section{Arne Egesten, Lund \\ Heiko Herwald, Lund}

\section{References}

1 Brinkmann V, Reichard U, Goosmann C, Fauler B, Uhlemann Y, Weiss DS, Weinrauch Y, Zychlinsky A: Neutrophil extracellular traps kill bacteria. Science 2004;303:15321535.

2 Sabbione F, Keitelman IA, Iula L, Ferrero M, Giordano MN, Baldi P, Rumbo M, Jancic C, Trevani AS: Neutrophil extracellular traps stimulate proinflammatory responses in human airway epithelial cells. J Innate Immun 2017;9:387-402.

3 Ramos MV, Mejias MP, Sabbione F, Fernandez-Brando RJ, Santiago AP, Amaral MM, Exeni R, Trevani AS, Palermo MS: Induction of neutrophil extracellular traps in Shiga toxin-associated hemolytic uremic syndrome. J Innate Immun 2016;8:400-411.

4 Engelmann B, Massberg S: Thrombosis as an intravascular effector of innate immunity. Nat Rev Immunol 2013;13:34-45.

5 Leffler J, Prohaszka Z, Mikes B, Sinkovits G, Ciacma K, Farkas P, Reti M, Kelen K, Reusz GS, Szabo AJ, Martin M, Blom AM: Decreased neutrophil extracellular trap degradation in Shiga toxin-associated haemolytic uraemic syndrome. J Innate Immun 2017;9: $12-21$.

6 Biron BM, Chung CS, O’Brien XM, Chen Y, Reichner JS, Ayala A: Cl-amidine prevents histone 3 citrullination and neutrophil extracellular trap formation, and improves survival in a murine sepsis model. J Innate Immun 2017;9:22-32.
7 Cooper PR, Palmer LJ, Chapple IL: Neutrophil extracellular traps as a new paradigm in innate immunity: friend or foe? Periodontol 2000 2013;63:165-197.

8 Sorensen OE, Borregaard N: Neutrophil extracellular traps - the dark side of neutrophils. J Clin Invest 2016;126:1612-1620.

9 Genga KR, Russell JA: Update of sepsis in the intensive care unit. J Innate Immun 2017;9: 441-455.

10 Okeke EB, Uzonna JE: In search of a cure for sepsis: taming the monster in critical care medicine. J Innate Immun 2016;8:156-170.

11 Tsujimoto H, Ono S, Efron PA, Scumpia PO, Moldawer LL, Mochizuki H: Role of toll-like receptors in the development of sepsis. Shock 2008;29:315-321.

12 Matzinger P: The danger model: a renewed sense of self. Science 2002;296:301-305.

13 Sansonetti PJ: The innate signaling of dangers and the dangers of innate signaling. Nat Immunol 2006;7:1237-1242.

14 Mijosek V, Lasitschka F, Warth A, Zabeck H, Dalpke AH, Weitnauer M: Endoplasmic reticulum stress is a danger signal promoting innate inflammatory responses in bronchial epithelial cells. J Innate Immun 2016;8:464478.

15 Yoon CM, Nam M, Oh YM, Dela Cruz CS, Kang MJ: Mitochondrial regulation of inflammasome activation in chronic obstructive pulmonary disease. J Innate Immun 2016; 8:121-128.

16 Fattahi F, Grailer JJ, Lu H, Dick RS, Parlett M, Zetoune FS, Nunez G, Ward PA: Selective biological responses of phagocytes and lungs to purified histones. J Innate Immun 2017;9: 300-317.
$17 \mathrm{Xu}$ J, Zhang X, Pelayo R, Monestier M, Ammollo CT, Semeraro F, Taylor FB, Esmon NL, Lupu F, Esmon CT: Extracellular histones are major mediators of death in sepsis. Nat Med 2009;15:1318-1321.

18 Herwald H, Dedio J, Kellner R, Loos M, Muller-Esterl W: Isolation and characterization of the kininogen-binding protein p33 from endothelial cells: identity with the gC1q receptor. J Biol Chem 1996;271:13040-13047.

19 Brown LF, Berse B, van de Water L, Papadopoulos-Sergiou A, Perruzzi CA, Manseau EJ, Dvorak HF, Senger DR: Expression and distribution of osteopontin in human tissues: widespread association with luminal epithelial surfaces. Mol Biol Cell 1992;3:1169-1180.

20 Westman J, Smeds E, Johansson L, Morgelin M, Olin AI, Malmstrom E, Linder A, Herwald $\mathrm{H}$ : Treatment with $\mathrm{p} 33$ curtails morbidity and mortality in a histone-induced murine shock model. J Innate Immun 2014;6:819-830.

21 Gela A, Bhongir RK, Mori M, Keenan P, Morgelin M, Erjefalt JS, Herwald H, Egesten A, Kasetty G: Osteopontin that is elevated in the airways during COPD impairs the antibacterial activity of common innate antibiotics. PLoS One 2016;11:e146192.

22 Neumann A, Papareddy P, Westman J, Hyldegaard O, Snall J, Norrby-Teglund A, Herwald $\mathrm{H}$ : Immunoregulation of neutrophil extracellular trap formation by endothelial-derived $\mathrm{p} 33$ (gC1q receptor). J Innate Immun 2018;10:30-43. 